\title{
Meningkatkan Konsentrasi Anak Attention Deficit Hyperactivity Disorder (ADHD) dengan Pendekatan Reinforcement melalui Metode Bermain "Bunchems"
}

\author{
Priskila Indah Putri ${ }^{1 凶}$, Ajeng Ayu Widiastuti \\ Prodi PG-PAUD Universitas Kristen Satya Wacana
}

\begin{abstract}
Abstrak
Penelitian ini bertujuan untuk mengetahui apakah reinforcement yang digunakan didalam permainan bunchems dapat meningkatkan konsentrasi anak dengan gangguan ADHD (Attention Deficit Hyperactivity Disorder). Penelitian ini dilakukan dengan menggunakan metode eksperimen dengan desain Eksperimen Subjek Tunggal. Dalam penelitian ini dilakukan dengan 12 sesi dengan pembagian 4 baseline dan 8 intervensi. Permainan yang digunakan dalam penelitian ini adalah bunchems dengan menggunakan teknik reinforcement. Didalam penelitian ini menggunakan 2 indikator yaitu; mengambil bunchems sesuai warna di instruksikan dan menyelesaikan permainan dengan waktu yang ditentukan.Dalam indicator tersebut diberikan teknik reinforcement, didalam indicator yang pertama reinforcement yang diberikan berupa pujian dan tepuk tangan, sedangkan pada indicator kedua memberikan reinforcement positive dan negative. Data yang diperoleh dianalisis dengan menggunakan analisis visual yang dibagi menjadi 2 yaitu dalam kondisi dan antar kondisi. Analisis ini dilakukan untuk mengetahui perubahan konsentrasi anak sebelum dan sesudah dilakukannya treatment reinforcement. Berdasarkan data analisis yang dilakukan dapat diambil kesimpulan bahwa teknik reinforcement dalam bermain bunchems memiliki pengaruh positif terhadap indicator mengambil bunchems sesuai warna di instruksikan dan menyelesaikan permainan dengan waktu yang ditentukan. Diharapkan penelitian dilakukan lebih lama dan peneliti lebih tegas terhadap subjek.
\end{abstract}

Kata kunci: $A D H D$, Konsentrasi, Reinforcement, Bunchems

\begin{abstract}
This study discusses the reinforcement used in bunchems games that can increase the attention of children with ADHD (Attention Deficit Hyperactivity Disorder) disorders. This research was conducted using an experimental method with the design of a Single Subject Experiment. In this study conducted with 12 sessions with the distribution of 4 baselines and 8 interventions. The game used in this study is bunchems using reinforcement techniques. This study uses 2 indicators, taking bunchems in accordance with the color is instructed and completing the game with the time specified. In this indicator a reinforcement technique is given. In the first indicator the reinforcement is given praise and applause, while the second indicator gives positive and negative reinforcement. The data obtained were analyzed using visual analysis collected into 2, analyzed in conditions and analyzed between conditions. This analysis was conducted to determine changes in concentration before and after improvement in treatment strengthening. Based on the data analysis carried out, conclusions can be drawn about strengthening techniques in playing bunchem having a positive influence on indicators taking a lot according to instructing and completing the game with the specified time. It would be better if the research take longer than before and the researcher more assertive to the subject.
\end{abstract}

Keyword : ADHD, Konsentrasi, Reinforcement, Bunchems

$\triangle$ Corresponding author :

Address: Jl. Diponegoro 52-60, Jawa Tengah, Indonesia

ISSN 2356-1327 (Media Cetak)

Email:272015005@student.uksw.edu

ISSN 2549-8959 (MediaOnline) 


\section{PENDAHULUAN}

Konsentrasi merupakan usaha untuk dapat memusatkan perhatian terhadap suatu objek (Nuryana \& Purwanto, 2010).Dalam setiap kegiatan membutuhkan konsentrasi, dengan adanya konsentrasi hasil yang ditunjukkan pada saat mengerjakan aktivitas lebih cepat selesai dan lebih baik (Hidayati, 2017). Maka anak ADHD harus bisa meningkatkan konsentrasinya, karna pada saat masuk ketingkat pendidikan yang lebih tinggi, menuntut anak untuk mengerjakan tugas.

ADHD yaitu anak yang mengalami ketidakmampuan unuk menjaga perhatiannya sehingga tidak dapat berkonsentrasi dalam menerima pelajaran (Amalia, 2018). Gangguan pemusatan perhatian yang sering muncul pada anak ADHD ini juga antara lain memiliki kesulitan mempertahankan fokus, tidak selesai dalam mengerjakan tugas, mudah terganggu oleh stimulus asing (Hatiningsih, 2013).

Belum adanya data resmi mengenai jumlah anak dengan gangguan ADHD di Indonesia, namun peneliti memperoleh data melalui infodatin yang dikeluarkan oleh Kementrian Kesehatan RI berdasarkan hasil Susesnas pada tahun 2012 menunjukkan bahwa terdapat penduduk yang menyandang disabilitas 2,45\% (Kementerian Kesehatan, 2014) Data lain yang didapatkan oleh peneliti menunjukkan bahwa di Amerika serikat ada sekitar 2$10 \%$ populasi anak sekolah menderita ADHD, sementara di Indonesia pada usia anak sekolah ada 2-4\% anak yang menderita ADHD (Makmum, 2011).

Berdasarkan penelitian yang dilakukan oleh Nuligar Hatiningsih (2013), Play Therapy dapat meningkatkan konsentrasi pada anak Attention Deficit Hyperctive Disorder (ADHD). Chandra, dkk (2016), konsentrasi belajar anak dapat meningkat melalui bermain papan. Reinschluessel, A. V., \& Mandryk, R. L. (2016), menggunakan positive or negative reinforcement dalam neurofeedback games untuk training self-regulation

Reinforcement merupakan proses dimana suatu perilaku diperkuat, dengan meningkatkan kecenderungan perilaku tersebut akan diulang dengan tujuan untuk menghilangkan perilaku yang tidak diinginkan atau untuk mengajari perilaku positif secara bertahap (Papalia, 2008).

Dalam penelitian ini, peneliti menyajikan meningkatkan konsentrasi anak Attention Deficit Hyperactivity Disorder (ADHD) dengan pendekatan Reinforcement melalu metode bermain bunchem.

\section{METODOLOGI}

Dalam penelitian ini menggunakan metode eksperimen subjek tunggal, dengan desain multiple baseline cross variables dengan dua kondisi A-B Penelitian subjek tunggal ini bertujuan untuk memodifikasi perilaku.. Kondisi baseline dilakukan selama 4 hari dengan indikator mengambil warna bunchem sesuai instruksi, menyelesaikan permainan sesuai waktu yang ditentukan, menyusun pola. Kondisi intervensi dilakukan selama 8 hari didalam mengambil warna bunchem sesuai instruksi reinforcement yang diberikan berupa pujian dan tepuk tangan, sedangkan pada indicator menyelesaikan permainan sesuai waktu yang ditentukan memberikan reinforcement positive dan negative.

Subjek penelitian dalam penelitian ini ialah seorang anak berusia 9 tahun dengan ADHD. Adapun teknik analisis data yang penulis gunakan adalah metode analisis visual. 


\section{HASIL DAN PEMBAHASAN}

Data hasil pelaksanaan penelitian selama 12 hari dibagi menjadi 2 fase yaitu 4 hari fase baseline dan 8 hari fase intervensi.

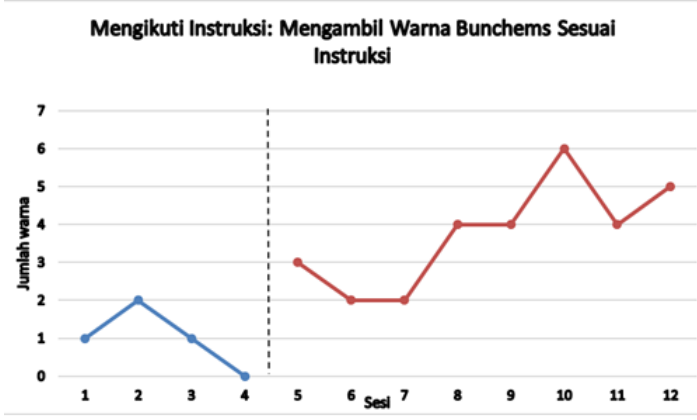

Gambar : Kondisi Baseline Dan Intervensi Dalam Mengikuti Instruksi Mengambil Warna Bunchems

Gambar di atas menjelaskan tentang perolehan data pada saat mengikuti instruksi mengambil warna bunchems. Kondisi baseline terdapat 4 sesi, yang dimulai dari sesi 1-4. Pada kondisi baseline peneliti hanya meminta kepada subjek untuk mengambilkan bunchems sesuai warna yang diucapkan, tanpa memberikan perlakuan. Pengukuran pada baseline 0-2. Pada fase intervensi terdapat 8 sesi, yang dimulai dari sesi 5-12. Pada fase ini peneliti memberikan reinforcement berupa pujian dan juga tepuk tangan ketika anak berhasil mengambil warna yang benar dengan yang peneliti instruksikan.

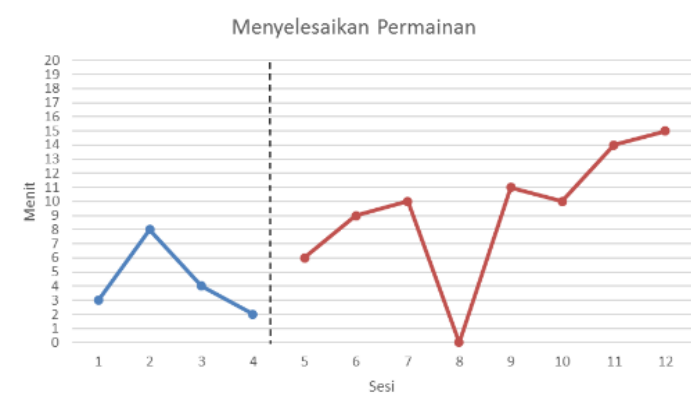

Gambar : Kondisi Baseline dan Intervensi Waktu Menyelesaikan Permainan

Gambar di atas menjelaskan tentang perolehan data pada saat menyelesaikan permainan sesuai dengan waktu yang ditentukan.. Pada kondisi baseline peneliti tidak memberikan reinforcement kepada anak. Pengukuran pada fase baseline perilaku pada rentang 2-8 menit. Pada fase intervensi dalam menyelesaikan permainan peneliti memberikan reinforcement kepada subjek. Reinforcement positif yang diberikan yaitu memberikan tambahan bunchems. Sedangkan reinforcement negative yang diberikan yaitu subjek mengembalikan bunchems. Reinforcement diberikan pada saat subjek berhasil bermain selama 5 menit dan kelipatannya. Reinforcement negative diberikan pada saat subjek tidak berhasil atau terganggu oleh lingkungan luar

\section{Analisis Dalam Kondisi}

Tabel 1. Analisis Dalam Kondisi

\begin{tabular}{|c|c|c|c|c|}
\hline \multirow[t]{2}{*}{ Kondisi } & \multicolumn{2}{|c|}{$\begin{array}{l}\text { Mengambil } \\
\text { Bunchems sesuai } \\
\text { warna yang } \\
\text { diminta }\end{array}$} & \multicolumn{2}{|c|}{$\begin{array}{c}\text { Menyelesaikan } \\
\text { permainan }\end{array}$} \\
\hline & A & B & A & B \\
\hline $\begin{array}{l}\text { Panjang } \\
\text { Kondisi }\end{array}$ & 4 & 8 & 4 & 8 \\
\hline \multirow{2}{*}{$\begin{array}{l}\text { Estimasi } \\
\text { kecenderung } \\
\text { an Arah }\end{array}$} & 1 & 1 & 1 & 1 \\
\hline & $(-)$ & $(+)$ & $(-)$ & $(+)$ \\
\hline \multirow{2}{*}{$\begin{array}{l}\text { Kecenderun } \\
\text { gan } \\
\text { Stabilitas }\end{array}$} & $\begin{array}{c}\text { Varia- } \\
\text { bel }\end{array}$ & $\begin{array}{c}\text { Varia- } \\
\text { bel }\end{array}$ & $\begin{array}{c}\text { Varia- } \\
\text { bel }\end{array}$ & $\begin{array}{c}\text { Varia } \\
\text {-bel }\end{array}$ \\
\hline & $50 \%$ & $38 \%$ & $50 \%$ & $38 \%$ \\
\hline \multirow{2}{*}{$\begin{array}{l}\text { Kecenderun } \\
\text { g-an Jejak }\end{array}$} & 1 & 1 & 1 & 1 \\
\hline & $(-)$ & $(+)$ & $(-)$ & $(+)$ \\
\hline \multirow{2}{*}{$\begin{array}{l}\text { Level } \\
\text { Stabilitas }\end{array}$} & $2-8$ & $6-15$ & $2-8$ & 6-15 \\
\hline & $\begin{array}{c}\text { Varia- } \\
\text { bel }\end{array}$ & $\begin{array}{c}\text { Varia- } \\
\text { bel }\end{array}$ & $\begin{array}{c}\text { Varia- } \\
\text { bel }\end{array}$ & $\begin{array}{c}\text { Varia } \\
\text {-bel }\end{array}$ \\
\hline \multirow{2}{*}{$\begin{array}{l}\text { Level } \\
\text { Perubahan }\end{array}$} & $0-1$ & $5-3$ & $2-3$ & $15-6$ \\
\hline & $(-1)$ & $(+2)$ & $(-1)$ & $(+11)$ \\
\hline
\end{tabular}

Kondisi yang dianalisis yaitu kondisi Baseline (A) dan kondisi Intervensi (B). Komponen analisis pada kemampuan Menyelesaikan Permainan Panjang kondisi pada baseline (A) 4 dan pada intervensi (B) 8. Kecenderungan arah yang ditunjukkan pada kondisi baseline negative (-) sedangkan pada kondisi intervensi mengatakan bahwa kecenderugan arah yang ditunjukkan positive (+). Kecenderungan 
stabilitas yang ditunjukkan pada kondisi baseline (50\%) tidak stabil atau bisa disebut juga variable dan pada kondisi intervensi $(38 \%)$ tidak stabil atau variable. Kecenderungan jejak yang ditunjukkan pada kondisi baseline (A) menurun (-) dan pada kondisi intervensi (B) meningkat (+). Level perubahan Jejak data pada kondisi baseline (A) $2-3=-1$ dan pada kondisi intervensi $(\mathrm{B}) 15-6=+11$.

\section{Analisis Antar kondisi}

Tabel 2 Analisis antar kondisi

\begin{tabular}{|c|c|c|c|c|}
\hline \multirow[t]{2}{*}{$\begin{array}{l}\text { Perbandingan } \\
\text { Kondisi }\end{array}$} & \multicolumn{2}{|c|}{$\begin{array}{c}\text { Mengambil } \\
\text { Bunchems } \\
\text { sesuai warna } \\
\text { yang diminta }\end{array}$} & \multicolumn{2}{|c|}{$\begin{array}{l}\text { Menyele } \\
\text { saikan } \\
\text { Permain } \\
\text { an } \\
\end{array}$} \\
\hline & \multicolumn{2}{|c|}{$\mathrm{B} / \mathrm{A}$} & \multicolumn{2}{|c|}{$\mathrm{B} / \mathrm{A}$} \\
\hline $\begin{array}{l}\text { Jumlah Variabel yang } \\
\text { diubah }\end{array}$ & \multicolumn{2}{|c|}{1} & \multicolumn{2}{|c|}{1} \\
\hline \multirow{3}{*}{$\begin{array}{c}\text { Perubahan } \\
\text { Kecenderungan Arah } \\
\text { dan Efeknya }\end{array}$} & 1 & I & 1 & / \\
\hline & $(-)$ & $(+)$ & $(-)$ & $(+)$ \\
\hline & \multicolumn{2}{|c|}{ Positif } & \multicolumn{2}{|c|}{ Positif } \\
\hline $\begin{array}{c}\text { Perubahan } \\
\text { Kecenderungan } \\
\text { Stabilitas }\end{array}$ & \multicolumn{2}{|c|}{$\begin{array}{c}\text { Variabel ke } \\
\text { Variabel }\end{array}$} & \multicolumn{2}{|c|}{$\begin{array}{c}\text { Variabel } \\
\text { ke } \\
\text { Variabel }\end{array}$} \\
\hline \multirow[t]{2}{*}{ Perubahan Level } & \multicolumn{2}{|c|}{$0-3$} & \multicolumn{2}{|c|}{$2-6$} \\
\hline & \multicolumn{2}{|c|}{$(+3)$} & \multicolumn{2}{|c|}{$(+4)$} \\
\hline Presentase Overlap & \multicolumn{2}{|c|}{$0 \%$} & \multicolumn{2}{|c|}{$0 \%$} \\
\hline
\end{tabular}

Analisis antar kondisi untuk mengetahui ada atau tidaknya pengaruh intervensi terhadap variable. Analisis antar kondisi dalam kemampuan mengikuti instruksi saat mengambil bunchems sesuai warna yang diminta memiliki sub variable yang akan diubah 1. Perubahan kecenderungan yang ditunjukkan yaitu meningkat $\quad(+)$ Kecenderungan stabilitasnya yaitu variable ke variable. Perubahan level dalam kemampuan ini meningkat +3 . Dalam kondisi ini intervensi yang diberikan menunjukkan bahwa berpengaruh namun tidak signifikan. Hal ini dapat dilihat pada overlap $0 \%$ yang menunjukkan bahwa berpengaruh, namun kecenderungannya dari variable ke variable.
Analisis antar kondisi untuk mengetahui ada atau tidaknya pengaruh intervensi terhadap variable. Analisis antar kondisi dalam menyelesaikan permainan memiliki sub variable yang akan diubah 1 . Perubahan kecenderungan yang ditunjukkan yaitu meningkat (+). Kecenderungan stabilitasnya yaitu variable ke variable. Perubahan level dalam kemampuan ini meningkat +4 . Dalam kondisi ini intervensi yang diberikan menunjukkan bahwa berpengaruh namun tidak signifikan. Hal ini dapat dilihat pada overlap $0 \%$ yang menunjukkan bahwa berpengaruh, namun kecenderungannya dari variable ke variable

Data yang dihasilkan dari sub variable diatas menunjukkan bahwa data tersebut tidak stabil. Data yang tidak stabil tersebut disebabkan karena jumlah baseline dan intervensi yang sedikit. Pada grafik 1 dan 2 menunjukkan bahwa data tersebut mendapatkan hasil bahwa data tersebut tidak overlap. Data tersebut tidak overlap disebabkan oleh data yang terdapat pada fase intervensi tidak ada yang masuk dalam batas atas maupun batas bawah pada fase baseline.

Menurut B.F Skinner (Papalia, 2008) Reinforcement dinilai dapat memperkuat tingkah laku yang diinginkan dalam penelitian ini tingkah laku yang diinginkan yaitu mengambil warna bunchems sesuai dengan instruksi yang diberikan dan menyelesaikan permainan sesuai dengan waktu yang ditentukan. Berdasarkan hasil penelitian yang dilakukan oleh peneliti reinforcement berpengaruh terhadap 2 perilaku yang diinginkan. Pada saat mengambil bunchems warna sesuai dengan instruksi reinforcement yang diberikan berupa pujian dan juga tepuk tangan. Pada saat menyelesaikan permainan, reinforcement yang diberikan berupa reinforcement positif (memberikan 
tambahan bunchems) dan juga reinforcement negative (mengembalikan bunchems).

Reinforcement yang dilakukan pada indicator menyelesaikan permainan yang dilakukan dapat meningkatkan konsentrasi anak dengan ADHD. Namun, dalam indicator yang kedua ini ada satu sesi yang dimana anak tidak mau melakukan kegiatan menyelesaikan permainan ini dikarenakan bertengkar dengan saudaranya. Factor eksternal ini dapat menyebabkan subjek tidak mau melakukan kegiatan sehingga reinforcement yang dilakukan tidak berpengaruh apapun dalam sesi tersebut.

Berdasarkan penelitian sebelumnya menerangkan bahwa play teraphy yang dilakukan dengan menggunakan permainan, dimana rumahku dapat meningkatkan konsentrasi pada anak ADHD. Didalam penelitian Nuligar melibatkan 3 subjek anak ADHD. Permainan dimana rumahku yang digunakan dapat meningkatkan konsentrasi karna melibatkan ransangan suara. Setelah treatment tersebut dilakukan konsentrasinya meningkat namun durasi konsentrasi subjek belum mengalami perubahan secara menyeluruh dan konsisten (Hatiningsih, 2013). Sama halnya dalam penelitian yang dilakukan oleh penulis untuk meningkatkan konsentrasi anak ADHD dengan menggunakan reinforcement dalam bermain bunchems. Dalam permainan bunchems, subjek mendapatkan reinforcement positive jika berhasil namun jika tidak mencapai target maka subjek mendapatkan reinforcement negative. Dalam penelitian yang dilakukan penulis mendapatkan hasil konsentrasi dapat meningkat dengan menggunakan reinforcement dalam permainan, akan tetapi durasi konsentrasi subjek tidak meningkat cukup besar.

Berdasarkan penelitian yang sebelumnya mengenai play therapy mengatakan bahwa play teraphy yang dilakukan mempunyai pengaruh yang positif terhadap pemusatan perhatian anak (El-Nagger, Abo-Elmagd, \& Ahmed, 2017). Namun dalam penelitian yang penulis lakukan mendapatkan data bahwa bermain mempunyai pengaruh positif terhadap konsentrasi anak.

Penelitian sebelumnya menerangkan bahwa Alderian Play Therapy dapat menjadi salah satu alternatif untuk meningkatkan berbagai kemampuan anak ADHD (Amalia, 2018). Dalam penelitian yang penulis lakukan mengatakan bahwa dengan bermain bunchems yang diiringi dengan reinforcement dapat meningkatkan konsentrasi anak. Terdapat 2 indikator yang disertai dengan reinforcement yaitu mengambil warna bunchems sesuai dengan instruksi dala, indicator ini diberikan reinforcement verbal, menyelesaikan permainan dengan waktu yang ditentukan yang diiringi oleh reinforcement.

Penelitian yang dilakukan oleh Chandra (2016) mengatakan bahwa melalui permainan papan titian konsentrasi anak dapat meningkat. Penelitian yang dilakukan oleh Candra melibatkan subjek anak-anak TK A di TK Indria dengan jumlah subjek 11 anak. Dengan menggunakan bermain permainan papan titian yang dilakukan dengan cara meniti diatas papan dapat meningkatakan konsentrasi anak karena dalam permainan ini meniti beratkan pada keterampilan anak dalam mengkoordinasikan gerak motoric, dan juga melibatkan kognitif yang dimana anak berfikir bagaimana caranya agar tidak terjatuh (Anam, ., \& D.S., 2018). Hasil yang diterima dalam penelitian yang dilakukan oleh Candra adanya peningkatan jumlah anak yang dapat meningkatkan konsentrasi belajar pada 2 siklus yang dilakukan. Dalam penelitian yang dilakukan oleh penulis bahwa konsentrasi anak dapat meningkat melalui permainan dapat 
mempengaruhi konsentrasi anak menjadi lebih baik. Konsentrasi anak dapat meningkatkan karena didalam permainan yang dilakukan dengan cara anak bermain menyusun bunchem sesuai pola yang melibatkan konsentrasi anak untuk mengikuti pola, anak juga membuat sesuatu dari bunchems dan ketika berhasil diberikannya reinforcement.

Penelitian sebelumnya mengatakan bahwa reinforcement yang dilakukan didalam penelitiannya dapat meningkatkan keaktifan siswa sehingga berpengaruh kepada hasil belajar siswa (Wulandari \& Masruri, 2016). Hal ini sama dengan penelitian yang penulis lakukan, bahwa dengan adanya reinforcement yang penulis berikan dapat membuat konsentrasi anak ADHD dapat meningkat.

Penelitian sebelumnya mengenai positive reinforcement menunjukkan bahwa dengan diberikannya positive reinforcement yang diberikan kepada subjek cukup efektif dalam meningkatkan kepercayaan subjek. Reinforcement positive yang diberikan oleh Riyati berupa pemberian pulsa 10.000 kepada subjek, ketika perilaku yang diharapkan muncul (Riyati, 2018). Didalam penelitian yang penulis lakukan juga terdapat reinforcement positive yang diberikan kepada subjek. Reinforcement positive yang diberikan kepada subjek dalam penelitian yang penulis lakukan yaitu yaitu memberikan tambahan bunchems ketika subjek dapat menyelesaikan permainan sesuai dengan waktu yang ditentukan. Dalam hal ini reinforcement bukan hanya dapat meningkatkan kepercayaan diri namun juga dapat meningkatkan konsentrasi anak.

Penelitian sebelumnya mengenai reinforcement positive dan reinforcement negative menunjukkan bahwa pengaruh yang dihasilkan dari reinforcement positive lebih efektif dibandingkan dengan reinforcement negative (Reinschluessel \& Mandryk, 2016). Didalam penelitian yang peneliti lakukan juga menggunakan reinforcement positive dan juga reinforcement negative. Reinforcement positive dilakukan pada indicator yang pertama berupa non verbal dan verbal, dan pada indicator kedua reinforcement positive yang dilakukan yaitu memberikan penambahan bunchems. Reinforcement negative diberikan hanya pada indicator 2 , yaitu mengembalikan bunchem ketika subjek tidak dapat menyelesaikan permainan dengan waktu yang ditentukan. Dalam penelitian yang peneliti lakukan reinforcement cukup efektif dalam meningkatkan konsentrasi anak dengan ADHD.

\section{KESIMPULAN}

Konsentrasi diperlukan di setiap kegiatan manusia, maka anak denganADHD harus bisa meningkatkan konsentrasinya. Oleh karena itu tujuan dari penelitian yang peneliti lakukan apakah dengan reinforcement melalui bermain bunchems dapat meningkatkan konsentrasi anak dengan gangguan ADHD. Menggunakan reinforcement dalam bermain bunchems dapat meningkatkan konsentrasi pada anak dengan gangguan ADHD. Hal ini ditunjukkan melalui grafik 1 sampai dengan grafik 2 menunjukkan data yang diperoleh variable ke variable. Pada grafik 1 dan 2 menunjukkan adanya perubahan konsentrasi pada subjek walaupun perubahan yang terjadi tidak signifikan.. Dengan demikian peneliti mengharapkan orangtua agar dapat tetap berusaha meningkatkan perhatian anak dalam mengerjakan kegiatan yang dilakukannya sampai selesai. Karena bagaimanapun konsentrasi sangat penting, dan di dalam kehidupan kita selalu menggunakan konsentrasi Pada penelitian 
selnjutnya hasil penelitian akan lebih efektif, jika penelitian yang dilakukan lebih dalam waktu yang lebih lama dan peneliti bersikap lebih tegas terhadap subjek.

\section{UCAPAN TERIMA KASIH}

Penulis mengucapkan terima kasih kepada keluarga subjek yang memberikan kesempatan kepada penulis untuk melakukan penelitian.

\section{DAFTAR PUSTAKA}

Amalia, R. (2018). Intervensi terhadap Anak Usia Dini yang Mengalami Gangguan ADHD Melalui Pendekatan Kognitif Perilaku dan Alderian Play Therapy. Jurnal Obsesi: Jurnal Pendidikan Anak Usia Dini, 2(1), 27. https://doi.org/10.31004/obsesi.v2i1.4

Anam, K., . P., \& D.S., A. C. (2018). Upaya Meningkatkan Kosentrasi Belajar Anak Melalui Bermain Papan Titian Di Tk Indria Desa Kutosari Kecamatan Gringsing Kabupaten Batang. Paudia : Jurnal Penelitian Dalam Bidang Pendidikan Anak Usia Dini, 6(2). https://doi.org/10.26877/paudia.v6i2.2 106

El-Nagger, N. S., Abo-Elmagd, M. H., \& Ahmed, H. I. (2017). Effect of applying play therapy on children with attention deficit hyperactivity disorder. Journal of Nursing Education and Practice, $\quad 7(5), \quad 104$. https://doi.org/10.5430/jnep.v7n5p104

Hatiningsih, N. (2013). Play Therapy Untuk Meningkatkan Konsentrasi pada Anak Attention Deficit Hyperctive Disorder (ADHD). Jurnal Ilmiah Psikologi Terapan, 01(02), 324-342.

Hidayati, R. (2017). Peran Konselor Sekolah Dalam Meningkatkan Konsentrasi Pada Siswa Hiperaktif (Adhd). Refleksi Edukatika, 5(1). https://doi.org/10.24176/re.v5i1.431
Kementerian Kesehatan. (2014). Situasi Penyandang Disabilitas. Situasi Penyandang Disabilitas, 2(1), 1-5. https://doi.org/10.1007/s13398-0140173-7.2

Nuryana, A., \& Purwanto, S. (2010). Efektivitas Brain Gym dalam Meningkatkan Konsentrasi Belajar pada Anak. Indigenous, Jurnal Ilmiah Berkala Psikologi, 12(1), 88-99. Retrieved from http://210.212.91.105:8080/jspui/handl e/123456789/895

Papalia, D. . \& etc. a. (2008). Human Development (Psikologi Perkembangan). In Cetakan ke-1, edisi ke-9. https://doi.org/10.1038/nature05019

Reinschluessel, A. V., \& Mandryk, R. L. (2016). Using Positive or Negative Reinforcement in Neurofeedback Games for Training Self-Regulation (pp. 186-198). https://doi.org/10.1145/2967934.29680 85

Riyati. (2018). Self Instructional Dan Positive Reinforcement Dalam Meningkatkan Kepercayaan Diri "Us" Penyandang Disabilitas Tubuh Di Balai Rehabilitasi Sosial Penyandang Cacat Cimahi. Pekerjaan Sosial, 15(2). https://doi.org/10.31595/peksos.v15i2. 88

Wulandari, R., \& Masruri, M. S. (2016). Peningkatan Hasil Belajar Ips Melalui Metode Simulasi Dengan Reinforcement Di Smpn 2 Jetis Bantul. Harmoni Sosial: Jurnal Pendidikan IPS, 3(1), 62. https://doi.org/10.21831/hsjpi.v3i1.969 6 